УДК 159.9

DOI https://doi.org/10.32689/maup.psych.2021.3.17

\title{
Яна ПОНОМАРЕНКО
}

кандидат психологічних наук, доцент кафедри соціології та психології, Харківський національний університет внутрішніх справ,

пр. Льва Ландау, 27, м. Харків, Україна, 61080

ORCID: 0000-0002-3374-3930

\section{Yana PONOMARENKO}

Candidate of Psychological Sciences (Ph.D.), Associate Professor at the Department of Sociology and Psychology, Kharkiv National University of Internal Affairs, 27 Lev Landau avenue, Kharkiv, Ukraine, 61080

ORCID: 0000-0002-3374-3930

\section{ОСОБЛИВОСТІ ЧАСОВОЇ ПЕРСПЕКТИВИ ПОЛЦЕЙСЬКИХ ІЗ РІЗНИМ РІВНЕМ ПРОФЕСІЙНОЇ САМОРЕАЛІЗАЦІЇ}

\author{
FEATURES OF THE TIME PERSPECTIVE \\ OF POLICE OFFICER'S WITH DIFFERENT LEVELS \\ OF PROFESSIONAL SELF-REALIZATION
}

\begin{abstract}
Представлено результати теоретичного й емпіричного вивчення особливостей часової перспективи полічейських у контексті їхньої професійної самореалізачї. Аналіз психологічної літератури показав, шьо планування власного професійного майбутнього позитивно позначається на якості виконуваної роботи поліиейськими, зумовлює їх задоволеність професією та реалізованістю в ній. Мета статті - вивчити особливості часової перспективи майбутнього у працівників поліиії з різним рівнем професійної самореалізачії. Наукова новизна дослідження полягає в тому, що поглиблено наявні знання щодо часової перспективи полічейських у контексті їхньої професійної самореалізації та вдосконалено емпіричні підходи до психологічної діагностики часової перспективи професійного майбутнього поліиейських. Вибірка дослідження становила 106 поліцейських. Згідно з даними опитувальника «Тип та рівень професійної самореалізації» $C$. Гаврилової з використанням кластерного аналізу за приниипом k-середніх досліджувані були розподілені за трьома групами. До першої групи увійшли 39 полічейських із низьким рівнем професійної самореалізаиії, до другої групи віднесені 23 досліджувані, які мають середній рівень професійної самореалізації, а третю групу становили 44 полічейські, які мали високі показники професійної самореалізації. Група із середнім рівнем професійної самореалізачії була виключена з подальшого дослідження. Також у дослідженні було використано «Опитувальник часової перспективи», розроблений Ф. Зімбардо. Висновки. Емпірично встановлено, шьо в поліцеейських із низьким рівнем професійної самореалізації виявлені ознаки травматичного попереднього професійного досвіду, який негативно впливає на їхнє сьогодення, щзо зумовлює впевненість у неконтрольованості перебігу подій та неможливості конструктивного вирішення проблемної чи кризової ситуацї; це стає причиною втрати віри у власну спроможність долати проблеми, попередити виникнення тих чи інших подій, знайти оптимальне вирішення в екстремальних обставинах. Поліцейським із високим рівнем професійної самореалізації притаманна позитивна оиінка минулого досвіду, вони відчувають упевненість у собі та у власній здатності вирішувати професійні завдання, щуо підвищує їхню професійну спроможність і компетентність.
\end{abstract}

Ключові слова: минулий досвід, поліцейські, професійне майбутнє, професійна самореалізація, часова перспектива.

The results of theoretical and empirical study of the peculiarities of the time perspective of police officers in the context of their professional self-realization are presented. The analysis of the psychological literature showed that the planning of one's own professional future has a positive effect on the quality of work performed by police officers, their satisfaction with the profession and realization in it. The aim of the article is to study the features of the time perspective of the future in police officers with different levels of professional self-realization. Scientific novelty of the study: deepened existing knowledge about the time perspective of police officers in the context of their professional self-realization and improved empirical approaches to the psychological diagnosis of the time perspective of the professional future of police officers. The sample included 106 police officers. According to the questionnaire "Type and level of professional self-realization" by Ye. Gavrylova using cluster analysis on the principle of $k$-means, the subjects were divided into three groups. The first group included 39 police officers with a low level of professional self-realization, the second group included 23 respondents who have an average level of professional self-realization, the third group consisted of 44 police officers who had high levels of professional self-realization. The group with an average level of professional self-realization was excluded from further research. The study used the "Questionnaire of Time Perspective" by F. Zimbardo. Conclusions. It has been empirically established that police officers with a low level of professional self-realization show signs of traumatic previous 
professional experience, which negatively affects their present, creates confidence in uncontrollability and inability to constructively resolve a problem or crisis situation. problems, prevent the occurrence of certain events, find the optimal solution in extreme circumstances. Policemen with a high level of professional self-realization are characterized by a positive assessment of previous experience, they feel confident in themselves and in their ability to solve professional problems, which increases their professional ability and competence.

Key words: past experience, police officers, professional future, professional self-determination, time perspective.

Постановка проблеми. Плинність кадрів поліції змушує замислитися над причинами цього явища та з'ясувати шляхи вирішення зазначеної проблеми. Робота в поліції є досить складною, що неодмінно призводить до фізичного, емоційного й психологічного виснаження, підштовхує її працівників до радикального заходу - звільнення. У науковій спільноті вчені сходяться в думці, що однією з можливих причин плинності поліцейських кадрів $\epsilon$ їх нереалізованість у професії та відсутність подальших перспектив уній. Саме це зумовило актуальність представленого дослідження.

Аналіз останніх досліджень і публікацій. У царині психологічної науки дослідники визначають поняття часової перспективи 3 фокусуванням уваги на різних ракурсах цього феномену. Так, А. Бунас пропонує розглядати часову перспективу як особистісний концепт, який формується 3 когнітивної системи та диференціює життя особистості в контексті минулого, теперішнього й майбутнього досвіду. При цьому часова перспектива здатна висвітлити особливості ціннісно-смислової системи людини, а також розкрити сенс життя [2, с. 39]. Своєю чергою О. Максим та Т. Рябовол вважають, що часова перспектива $\epsilon$ когнітивним відображенням мотивації людини, що містить у собі мрії, сподівання, плани, прагнення, устремління, страхи, котрі підвладні подіям минулого, теперішнього й майбутнього. Науковиці зазначають, що часова перспектива $є$ показником життєвої стратегії людини, адже вона впродовж усього свого життєвого шляху долає труднощі та кризові ситуації, які чинять істотний вплив на побудову подальших перспектив [6, с. 283]. На переконання О. Журавльової, недостатня сформованість часової перспективи зменшує здатність особистості встановлювати й реалізовувати цілі, змінює організацію та екстраполяцію поведінки в часі, адже думки про майбутнє $\epsilon$ фундаментом для побудови усвідомленої психічної діяльності [5, с. 156].

У більшості досліджень зазначається, що для кращого розуміння процесу проєктування власного майбутнього необхідно звертати увагу на специфіку конструювання майбутнього особистістю. Так, М. Дворник вважає, що схожим на самопрогнозування за способом творення і своїми функціями $є$ поняття конструювання життєвої перспективи. Авторка підкреслює, що емпіричне вивчення особливостей життєвої перспективи здатне розширити межі розуміння майбутнього особистості в контексті їі відповідальності, прийняття рішень, зрілості та соціальної активності [3, с. 12]. В. Діброва дотримується схожої думки та стверджує, що ознаками конструйованого майбутнього $\epsilon$ гнучкість, поетапність цього процесу, організованість i присутність творчого складника в діяльності, формулюванні життєвих планів. Істотним фундаментом у процесі побудови життєвих планів, на думку дослідниці, $є$ минулий i теперішній досвід [4, с. 30].

Щодо особливостей конструювання майбутнього поліцейських у контексті часової перспективи Н. Мілорадова пропонує звертати увагу на особливості професійного сценарного планування, що розкриває послідовний план поліцейського до самореалізації у професії [7, с. 154]. Н. Афанасьєва встановила, що задоволеність життям у представників ризиконебезпечних професій залежить від наявності в них планів на майбутнє, постановки цілей, котрі доповнюють життя усвідомленістю, спрямованістю та часовою перспективою. Авторка вважає, що ставлення до життєвого часу у фахівців екстремальних професій визначає присутність чи відсутність схильності до усвідомлення часу власного життя [1]. На думку Д. Швеця та співавторів, для гармонійного розвитку поліцейського у професії особливого значення набуває усвідомлення поліцейським свого місця в ній та подальших перспектив розвитку [12]. В. Бондаренко 3 колегами підтверджують, що професійна успішність поліцейського зумовлена його здатністю адаптуватися у професії та будувати перспективи свого майбутнього в ній [10]. Результати дослідження, проведеного колективом авторів на чолі 3 K. Papazoglou, доводять, що високоефективний поліцейський - це той, хто розділяє цінності професії та прагне розвиватися в ній [11].

Метою дослідження $є$ вивчення особливостей часової перспективи майбутнього у працівників поліції з різним рівнем професійної самореалізації. Для iï досягнення необхідно було виконати такі завдання: 1) провести теоретичний аналіз наукових напрацювань із проблеми часової перспективи майбутнього поліцейських; 2) визначити особливості часової перспективи майбутнього в поліцейських із різним рівнем професійної самореалізації. 
Наукова новизна дослідження полягає в тому, що воно поглибило наявні знання щодо часової перспективи поліцейських у контексті їхньої професійної самореалізації. Було вдосконалено емпіричні підходи до психологічної діагностики часової перспективи професійного майбутнього поліцейських.

Результати досліджень. Для досягнення поставленої мети нами було проведено емпіричне дослідження особливостей часової перспективи на працівниках поліції із різним рівнем професійної самореалізації. Загальна чисельність вибірки дослідження налічувала 106 поліцейських. За допомогою застосування опитувальника «Тип та рівень професійної самореалізації» Є. Гаврилової з використанням кластерного аналізу за принципом k-середніх нами було поділено досліджуваних за трьома групами. До першої групи увійшли 39 поліцейських із низьким рівнем професійної самореалізації, до другої групи віднесені 23 досліджувані, які мають середній рівень професійної самореалізації, а третю групу становили 44 поліцейські, які мали високі показники професійної самореалізації. Група із середнім рівнем професійної самореалізації була виключена 3 подальшого дослідження. За допомогою «Опитувальника часової перспективи» Ф. Зімбардо було діагностовано ставлення поліцейських із різним рівнем професійної самореалізації до часового континууму. Опитувальник містить 56 тверджень, що поділені за п'ятьма шкалами: 1) негативне минуле; 2) гедоністичне сьогодення; 3) майбутнє; 4) позитивне минуле; 5) фаталістичне сьогодення [8, с. 99-105]. Математико-статистична обробка здійснювалася з використанням $\mathrm{t}$-критеріюСтьюдентадлянезалежних вибірок.

Показники часової перспективи в поліцейських із різним рівнем професійної самореалізації наведено в таблиці 1 .

Встановлено, що за шкалою «Негативне минуле» спостерігаються значущі відмінності в досліджуваних групах $(\mathrm{p} \leq 0,05)$. Вірогідно більший показник за цією шкалою, встановлений у групі поліцейських із низьким рівнем професійної самореалізації, свідчить про те, що ці досліджувані занадто переймаються подіями минулого, які мали травматичний або стресовий характер, що неодмінно ускладнює виконання їхніх професійних обов'язків, оскільки вони відчувають страхи щодо повторення негативної події та мають сумніви стосовно своїх можливостей самостійно вирішити проблемну ситуацію. На відміну від працівників поліції з високим рівнем професійної самореалізації, вірогідно більш низькі показники у групі поліцейських iз низьким рівнем професійної самореалізації були встановлені також за шкалою «Фаталістичне сьогодення» $(\mathrm{p} \leq 0,05)$. Отримані результати викликають занепокоєння, оскільки демонструють більшу схильність цих респондентів до думок щодо власної безпорадності та неможливості вплинути на перебіг подій. Тобто представники першої групи, які досить невпевнено почувають себе у професії, схильні вважати, що все, що має відбутися, врешті-решт здійсниться незалежно від того, чи будуть вони докладати зусилля, щоб попередити виникнення проблемної ситуації. Ця тенденція потребує особливої уваги, адже обов'язок поліцейського вимагає від нього захисту закону та прав людини, здоров'я i життя якої він повинен зберегти, докладаючи максимум зусиль незалежно від обставин.

Виявлено, що за шкалою «Позитивне минуле» показник у групі поліцейських із високим рівнем професійної самореалізації вірогідно перевищує відповідний показник у поліцейських із низьким рівнем професійної самореалізації $(\mathrm{p} \leq 0,05)$. Отже, отримані дані дають можливість вважати, що минулий позитивний досвід $є$ більш значущим для поліцейських із високим рівнем професійної самореалізації. Досягнення успіху приводить до почуття впевненості у власних силах i надає натхнення для подальшого вдосконалення своєї майстерності. Професійні ситуації позитивної забарвленості, які мали істотне значення для представників цієї групи, стають чинником, що мотивує працівників полі-

Показники часової перспективи майбут

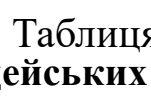

$(\mathbf{M} \pm \mathbf{m})$

\begin{tabular}{|l|c|c|c|c|}
\hline \multicolumn{1}{|c|}{ Шкали } & $\begin{array}{c}\text { Поліцейські 3 низьким } \\
\text { рівнем професійної } \\
\text { самореалізації }\end{array}$ & $\begin{array}{c}\text { Поліцейські з високим } \\
\text { рівнем професійної } \\
\text { самореалізації }\end{array}$ & $\mathbf{t}$ & $\mathbf{p}$ \\
\hline Негативне минуле & $3,95 \pm 0,69$ & $2,08 \pm 0,62$ & 2,02 & 0,05 \\
\hline Гедоністичне сьогодення & $3,17 \pm 0,57$ & $3,20 \pm 0,49$ & 0,04 & - \\
\hline Майбутнє & $3,77 \pm 0,53$ & $3,85 \pm 0,52$ & 0,11 & - \\
\hline Позитивне минуле & $2,64 \pm 0,48$ & $3,96 \pm 0,45$ & 2,01 & 0,05 \\
\hline Фаталістичне сьогодення & $3,86 \pm 0,63$ & $2,11 \pm 0,61$ & 2,00 & 0,05 \\
\hline
\end{tabular}


ції продовжувати займатися своєю професійною діяльністю, оскільки підтверджують їхню здатність впливати власними діями на перебіг ситуації та приносити користь іншим і суспільству загалом.

За шкалами «Гедоністичне сьогодення» $(\mathrm{t}=0,04)$ та «Майбутнє» $(\mathrm{t}=0,11)$ вірогідні відмінності між досліджуваними групами не були встановлені. Отже, поліцейські незалежно від рівня професійної самореалізації досить задоволені життям, проте водночас ця задоволеність не трансформована в надмірний гедонізм, котрий передбачає «роз'єднаність» минулого й майбутнього, пошук збудження та брак стурбованості щодо майбутніх наслідків поведінки. Представникам обох груп притаманна активна життєва позиція, самостійність щодо побудови свого життя відповідно до власних цілей і цінностей. Рівень професійної самореалізації не відбивається у формуванні перспективи майбутнього в поліцейських під час виконання службових завдань, однак демонструє їхню автономність у прийнятті рішень та планах щодо власного професійного майбутнього.

Висновки. Проведене дослідження дало змогу висвітлити особливості часової перспективи майбутнього у представників правоохоронних органів. Під час теоретичного аналізу встановлено, що планування власного професійного майбутнього є чинником профілактики плинності поліцейських кадрів, запорукою їхньої успішної самореалізації та надає можливості подальшого професійного розвитку. Емпіричне дослідження свідчить про те, що в поліцейських із низьким рівнем професійної самореалізації виявлені ознаки травматичного попереднього професійного досвіду, який негативно впливає на їхнє сьогодення, що зумовлює впевненість у неконтрольованості перебігу подій та неможливості конструктивного вирішення проблемної чи кризової ситуації; це стає причиною втрати віри у власну спроможність долати проблеми, попередити виникнення тих чи інших подій, знайти оптимальне вирішення в екстремальних обставинах. Поліцейським із високим рівнем професійної самореалізації притаманна позитивна оцінка попереднього досвіду, вони відчувають упевненість у собі та у власній здатності вирішувати професійні завдання, що підвищує їхню професійну спроможність i компетентність. Для обох досліджуваних груп характерна задоволеність сьогоденням (що водночас не трансформована в надмірний гедонізм), активна життєва позиція, самостійність у конструюванні перспектив власного життя відповідно до сформованих ними цілей і цінностей, здатність до автономного прийняття рішень та планування свого майбутнього упрофесійному й життєвому контекстах.

Перспективи подальших наукових досліджень ми вбачаємо в поглибленому аналізі психологічних характеристик, які дадуть можливість деталізувати чинники формування професійної самореалізації та професійної здійсненності поліцейських як умови їх ефективної професійної діяльності.

\section{Література:}

1. Афанасьєва Н. Застосування наративу у психологічному консультуванні рятувальників - учасників ООС з порушеннями часової орієнтації. Украӥнський психологічний журнал. 2019. № 1(11). С. 28-38. URL: https://doi.org/10.17721/upj.2019.1(11).2.

2. Бунас А. Часова перспектива як один із чинників розгортання прогностичної компетентності особистості. Дніпровський науковий часопис публічного управління, психологї̈, права. 2020. № 1. С. 38-41. URL: https://doi.org/10.51547/ppp.dp.ua/2020.1.6.

3. Дворник М. Прокрастинація в конструюванні особистісного майбутнього : монографія. Кропивницький : Імекс-ЛТД, 2018. 120 с.

4. Діброва В. Пошукове дослідження особливостей конструювання майбутнього внутрішньо переміщеними особами. Вісник Київського інституту бізнесу та технологій. 2020. Т. 45. № 3. С. $27-35$. URL: https://doi.org/10.37203/10.37203/kibit.2020.45.04.

5. Журавьова О. Роль особливостей часової перспективи особистості у формуванні схильності до прокрастинації. Психологічний часопис. 2020. № 6. C. 154-163. URL: https://doi.org/10.31108/ 1.2020.6.3.15.

6. Максим О., Рябовол Т. Усвідомлення часової перспективи-умова становлення ціннісних орієнтацій особистості. Молодий вчений. 2021. № 5(93). С. 282-285. URL: https://doi.org/10.32839/2304-5809/2021-593-53.

7. Мілорадова Н. Сценарні тенденції професіогенезу слідчих органів досудового розслідування Національної поліції України. Право і безпека. 2020. № 1(76). С. 153-161. URL: https://doi.org/10.32631/ pb.2020.1.22.

8. Психодиагностика стресса : практикум / сост. : Р. Куприянов, Ю. Кузьмина. Казань : КНИТУ, 2012. $212 \mathrm{c}$.

9. Formation of the Professionally Significant Skills and Competencies of Future Police Officers during Studying at Higher Educational Institutions / V. Bondarenko, I. Okhrimenko, I. Tverdokhvalova, K. Mannapova, 
K. Prontenko. Revista Românească pentru Educaţie Multidimensională. 2020. Vol. 12. № 3. P. 246-267. URL: https://doi.org/10.18662/rrem/12.3/320.

10. Addressing moral suffering in police work: theoretical conceptualization and counselling implications / K. Papazoglou, D. Blumberg, K. Kamkar, A. McIntyre-Smith, M. Koskelainen. Canadian Journal of Counselling and Psychotherapy. 2020. Vol. 54. № 1. P. 71-87. URL: https://cjc-rcc.ucalgary.ca/article/view/68490.

11. The New Police Training System: Psychological Aspects / D. Shvets, O. Yevdokimova, I. Okhrimenko, Ya. Ponomarenko, Yu. Aleksandrov, S. Okhrimenko, K. Prontenko. Postmodern Openings. 2020. Vol. 11. № 1. P. 200-217. URL: https://doi.org/10.18662/po/11.1sup1/130.

\section{References:}

1. Afanasieva, N. (2019). Zastosuvannia naratyvu u psykholohichnomu konsultuvanni riatuvalnykiv uchasnykiv OOS z porushenniamy chasovoi oriientatsii [Application of narratives in psychological consultation of rescuers - JFO participants having problems with time perspective]. Ukrainskyi psykholohichnyi zhurnal Ukrainian Psychological Journal, 1(11), 28-38. Retrieved from: https://doi.org/10.17721/upj.2019.1(11).2 [in Ukrainian].

2. Bunas, A. (2020). Chasova perspektyva yak odyn iz chynnykiv rozghortannia prohnostychnoi kompetentnosti osobystosti [Time perspective as one of the factors of development of predictive personality competence]. Dniprovskyi naukovyi chasopys publichnoho upravlinnia, psykholohii, prava - Dnipro Scientific Journal of Public Administration, Psychology, Law, 1, 38-41. Retrieved from: https://doi.org/10.51547/ppp. dp.ua/2020.1.6 [in Ukrainian].

3. Dvornyk, M. (2018). Prokrastynatsiia v konstruiuvanni osobystisnoho maibutnoho: monohrafiia [Procrastination in the construction of a personal future: monograph]. Kropyvnytskyi: Imeks-LTD [in Ukrainian].

4. Dibrova, V. (2020). Poshukove doslidzhennia osoblyvostei konstruiuvannia maibutnoho vnutrishno peremishchenymy osobamy [Exploratory research of peculiarities of constructing the future by the internally displaced persons]. Visnyk Kyivskoho instytutu biznesu ta tekhnolohii - Herald of Kiev Institute of Business and Technology, 45(3), 27-35. Retrieved from: https://doi.org/10.37203/10.37203/kibit.2020.45.04 [in Ukrainian].

5. Zhuravleva, O. (2020). Rol osoblyvostei chasovoi perspektyvy osobystosti u formuvanni skhylnosti do prokrastynatsii [The role of an individual's temporal perspective peculiarities in procrastination propensity formation]. Psykholohichnyi chasopys - Psychological journal, 6, 154-163. Retrieved from: https://doi. org/10.31108/1.2020.6.3.15 [in Ukrainian].

6. Maksym, O., \& Ryabovol, T. (2021). Usvidomlennia chasovoi perspektyvy - umova stanovlennia tsinnisnykh oriientatsii osobystosti [Awareness of time perspective as a condition required for the formation of value orientations of personality]. Molodyi vchenyi - Young Scientist, 5(93), 282-285. Retrieved from: https:// doi.org/10.32839/2304-5809/2021-5-93-53 [in Ukrainian].

7. Miloradova, N. (2020). Stsenarni tendentsii profesiohenezu slidchykh orhaniv dosudovoho rozsliduvannia Natsionalnoi politsii Ukrainy [Scenario tendencies of professional genesis of investigators of pre-trial investigation agencies of the National police of Ukraine]. Pravo i bezpeka - Law and Safety, 1(76), 153-151. Retrieved from: https://doi.org/10.32631/pb.2020.1.22 [in Ukrainian].

8. Kupriyanov, R., \& Kuz'mina, Yu. (eds.). (2012). Psihodiagnostika stressa: praktikum [Psychodiagnostics of stress: practical work]. Kazan: KNITU [in Russian].

9. Bondarenko, V., Okhrimenko, I., Tverdokhvalova, I., Mannapova, K., \& Prontenko, K. (2020). Formation of the Professionally Significant Skills and Competencies of Future Police Officers during Studying at Higher Educational Institutions. Revista Românească pentru Educaţie Multidimensională, 12(3), 246-267. Retrieved from: https://doi.org/10.18662/rrem/12.3/320 [in English].

10. Papazoglou, K., Blumberg, D., Kamkar, K., McIntyre-Smith, A., \& Koskelainen, M. (2020). Addressing moral suffering in police work: theoretical conceptualization and counselling implications. Canadian Journal of Counselling and Psychotherapy, 54(1), 71-87. Retrieved from: https://cjc-rcc.ucalgary.ca/article/ view/68490 [in English].

11. Shvets, D., Yevdokimova, O., Okhrimenko, I., Ponomarenko, Ya., Aleksandrov, Yu., Okhrimenko, S., \& Prontenko, K. (2020). The New Police Training System: Psychological Aspects. Postmodern Openings, 11(1), 200-217. Retrieved from: https://doi.org/10.18662/po/11.1sup1/130 [in English]. 